Canadian University Music Review

Revue de musique des universités canadiennes

\title{
Errata for Canadian University Music Review
}

Volume 16, numéro 2, 1996

URI : https://id.erudit.org/iderudit/1014423ar

DOI : https://doi.org/10.7202/1014423ar

Aller au sommaire du numéro

Éditeur(s)

Canadian University Music Society / Société de musique des universités

canadiennes

ISSN

0710-0353 (imprimé)

2291-2436 (numérique)

Découvrir la revue

Citer ce document

(1996). Errata for Canadian University Music Review. Canadian University Music Review / Revue de musique des universités canadiennes, 16(2).

https://doi.org/10.7202/1014423ar

All Rights Reserved (C Canadian University Music Society / Société de musique des universités canadiennes, 1996
Ce document est protégé par la loi sur le droit d'auteur. L’utilisation des services d'Érudit (y compris la reproduction) est assujettie à sa politique d'utilisation que vous pouvez consulter en ligne.

https://apropos.erudit.org/fr/usagers/politique-dutilisation/ 


\section{Errata for Canadian University Music Review}

Because of a problem in communication, errors in Carol E. Harris' essay were not corrected in the printed copy of CUMR 16/2 (1996). The important points to note are as follows:

p. 111 second paragraph, line 7, "require" not "requite"

p. 112 second line after "Discussion," "benefit" not "benefits"

p. 114 note 68, "Collingwood, Essays in the Philosophy of Art. Bloomington: Indiana University Press, 1964."

p. 114 note 70, “Collingwood, Essays, 196."

p. 114 the call for note 71 should appear after the reference to Ministry documents in paragraph three.

p. 114 note 72, "See Collingwood, Principles, Chapter XIV."

p. 115 line 5, "offer these children."

Please insert this sheet into your copy of Canadian University Music Review, Volume 16/2. 